\title{
Role of key-regulator genes in melanoma susceptibility and pathogenesis among patients from South Italy
} Milena Casula1 ${ }^{1}$ Antonio Muggiano ${ }^{2}$, Antonio Cossu ${ }^{3}$, Mario Budroni ${ }^{4}$, Corrado Caracò ${ }^{5}$, Paolo A Ascierto ${ }^{5}$, Elena Pagani ${ }^{6}$, Ignazio Stanganelli ${ }^{7}$, Sergio Canzanella ${ }^{8}$, MariaCristina Sini ${ }^{1}$, Grazia Palomba1, The Italian Melanoma Intergroup (IMI) and Giuseppe Palmieri*1

Address: ${ }^{1}$ Istituto di Chimica Biomolecolare, Consiglio Nazionale delle Ricerche, Sassari, Italy, ${ }^{2}$ Oncologia Medica 1, Ospedale Oncologico Businco, Cagliari, Italy, ${ }^{3}$ Servizio di Anatomia Patologica, Azienda Ospedaliero Universitaria, Sassari, Italy, ${ }^{4}$ Servizio di Epidemiologia, Azienda Sanitaria Locale 1, Sassari, Italy, ${ }^{5}$ Istituto Nazionale Tumori Fondazione Pascale, Napoli, Italy, ${ }^{6}$ Istituto Dermopatico dell'Immacolata, Roma, Italy, ${ }^{7}$ Istituto Tumori Romagna, Meldola, Forli, Italy and ${ }^{8}$ Associazione House Hospital Onlus, Napoli, Italy

Email: Milena Casula - casulam@yahoo.it; Antonio Muggiano - amuggi@tin.it; Antonio Cossu - cossu@uniss.it; Mario Budroni - mariobudroni@tiscalinet.it; Corrado Caracò - corracara@fastwebnet.it; Paolo A Ascierto - pasciert@tin.it; Elena Pagani - e.pagani@idi.it; Ignazio Stanganelli - igstanga@tin.it; Sergio Canzanella - househospital@tin.it;

MariaCristina Sini - mc.sini@tiscali.it; Grazia Palomba - graziap68@yahoo.it; The Italian Melanoma Intergroup (IMI) - alessandro.testori@ieo.it; Giuseppe Palmieri* - gpalmieri@yahoo.com

* Corresponding author

Published: 3 October 2009

BMC Cancer 2009, 9:352 doi:10.1 |86//47|-2407-9-352
Received: 3 April 2009

Accepted: 3 October 2009

This article is available from: http://www.biomedcentral.com/I47I-2407/9/352

(c) 2009 Casula et al; licensee BioMed Central Ltd.

This is an Open Access article distributed under the terms of the Creative Commons Attribution License (http://creativecommons.org/licenses/by/2.0), which permits unrestricted use, distribution, and reproduction in any medium, provided the original work is properly cited.

\begin{abstract}
Background: Several genetic alterations have been demonstrated to contribute to the development and progression of melanoma. In this study, we further investigated the impact of key-regulator genes in susceptibility and pathogenesis of such a disease.

Methods: A large series $(N=846)$ of sporadic and familial cases originating from South Italy was screened for germline mutations in p/6CDKN2A, BRCA2, and MCIR genes by DHPLC analysis and automated DNA sequencing. Paired primary melanomas and lymph node metastases from same patients $(N=35)$ as well as melanoma cell lines $(N=18)$ were analyzed for somatic mutations in NRAS, BRAF, and p / 6CDKN2A genes.

Results: For melanoma susceptibility, investigations at germline level indicated that $p / 6^{C D K N 2 A}$ was exclusively mutated in $16 / 545$ (2.9\%) non-Sardinian patients, whereas BRCA2 germline mutations were observed in 4/91 (4.4\%) patients from North Sardinia only. Two MCIR germline variants, ArgI5ICys and Asp294His, were significantly associated with melanoma in Sardinia. Regarding genetic events involved in melanoma pathogenesis at somatic level, mutually-exclusive mutations of NRAS and BRAF genes were observed at quite same rate (about two thirds) in cultured and in vivo melanomas (either primary or metastatic lesions). Conversely, p $/ 6^{C D K N 2 A}$ gene alterations were observed at increased rates moving from primary to metastatic melanomas and melanoma cell lines. Activation of the ERK gene product was demonstrated to be consistently induced by a combination of molecular alterations (NRAS/BRAF mutations and p/ 6 CDKN2A silencing).
\end{abstract}

Conclusion: Our findings further clarified that: $a$ ) mutation prevalence in melanoma susceptibility genes may vary within each specific geographical area; $b$ ) multiple molecular events are accumulating during melanomagenesis. 


\section{Background}

In fair skinned populations, both incidence and mortality rates of melanoma have been increasing over the past decades [1]. Fortunately, the most recent data on the melanoma epidemic suggest that majority of melanoma patients presents with thin lesions (Breslow thickness $\leq$ $1.00 \mathrm{~mm}$ ) at the time of diagnosis, due to a steady improvement of the secondary prevention and early detection [2].

Baseline melanoma incidences have been found to vary according to the population's origin: Australia, the United States, and Sweden present a higher baseline incidence than Europe (except Sweden) [3,4]. Considering the European population, there is a gradient of melanoma incidence moving from northern countries (where incidence is higher) to southern countries [5]. In Italy, different incidence rates of melanoma between the northern and southern parts of the country (standardized rates per year per 100.000 inhabitants: 10.5-13.5 in North Italy versus 3.5-4.5 in South Italy) have been also reported [5].

Environmental and, mostly, genetic factors have been demonstrated to participate in susceptibility and pathogenesis of human melanoma. An intermittent exposure to ultraviolet radiation, especially in combination with endogenous factors like skin type and number of nevi, is the most commonly involved environmental factor [6-9].

From the genetic point of view, several gene alterations have been implicated. Germline mutations in $p 16$ CDKN2A gene represent the most recognized cause of inherited melanoma susceptibility. Prevalence of $p 16^{C D K N 2 A}$ mutations seems to be heterogeneously distributed among melanoma patients within different geographical areas [10]; our previous study on melanoma patients originating from South Italy indicated that $p 16^{C D K N 2 A}$ mutations were absent in North Sardinia and occurred in non-Sardinian patients only [11]. Several low-penetrance candidate genes, such as breast cancer susceptibilitygene 2 (BRCA2) and melanocortin-1-receptor (MC1R), have been also implicated in melanoma predisposition $[12,13]$. Inherited mutations of the BRCA2 gene have been associated to development of both ocular and cutaneous melanomas, in addition to the main predisposition to breast and ovarian cancers [12-14]. The MC1R gene encodes the melanocyte-stimulating hormone receptor (MSHR), a member of the G-protein-coupled receptor superfamily and represents one of the major genes which determine skin pigmentation [15-17]. The MC1R gene is remarkably polymorphic in Caucasian populations [18]; its sequence variants can result in partial (r) or complete (R) loss of the receptor's signalling ability [19]. The MC1R variants were suggested to be associated with red hair, fair skin, and increased risk of both melanoma and non- melanoma skin cancers [18-21]. Moreover, melanomas developed on skin not chronically exposed to sun usually carry either a mutated NRAS or mutated BRAF or concurrently mutated BRAF and PTEN [22]; evidence indeed suggest that BRAF/PTEN and NRAS somatic mutations are mutually exclusive or, in other words, that both mutation subsets does not occur in the same melanoma cell [2225]. Finally, the ERK1-2 proteins, which represent the downstream components of the NRAS-BRAF-MEK signaling kinase cascade, have been found to be activated through phosphorilation $\left(\mathrm{pERK}_{1-2}\right)$ in melanoma and implicated in rapid malignant cell growth, mostly as a consequence of mutations in upstream components of the pathway [25-27].

The aim of the present study was to evaluate the spectrum of such genetic alterations in both germline DNA, using a clinic-based series of sporadic and familial melanomas from South Italy (including cases from the entire Sardinia island), and somatic DNA, using a subset of melanoma tissues and cell lines. Correlations between genetic alterations and melanoma susceptibility or pathogenesis was thus inferred.

\section{Methods \\ Melanoma cases}

Eight hundred and forty-six patients with histologicallyproven diagnosis of cutaneous melanoma were included into the study. Among them, 301 originated from Sardinia and 545 from other southern Italian regions; no substantial difference was observed in patients' characteristics between the Sardinian and non-Sardinian series. To avoid any bias, patients were consecutively collected from January 2001 to December 2006; they were included regardless of age of onset, cancer family history, and disease characteristics. Moreover, 35 melanoma tissues (paraffin-embedded primary melanomas and frozen samples from synchronous or asynchronous lymph node metastases of the same patients) and 18 melanoma cell lines (cultured from primary and metastatic tumours - see below) were collected.

Clinical and pathological features such as histological classification (including Breslow thickness) and disease stage at diagnosis were confirmed by medical records, review of pathologic material, and/or pathology reports. Familial recurrence of melanoma was ascertained by using a questionnaire to interview probands about their first-, second-, and third-degree relatives. Melanoma families were identified according to standardized criteria [23]: $a$ ) at least three affected members, or $b$ ) two affected members and presence of at least one of the following subcriteria: $i$ ) at least one affected member younger than 50 years at onset, or $i$ ) a case of pancreatic cancer in a first- or second-degree relative, or iii) one affected member with mul- 
tiple primary melanomas. Patients were informed about aims and limits of the study and blood samples were obtained with their written consent.

The study was reviewed and approved by the ethical review boards of both Azienda USL1 and University of Sassari.

\section{Mutation screening of candidate genes}

For mutation analysis, genomic DNA was isolated from peripheral blood samples or tumour tissues or melanoma cell lines, using standard methods. At germline DNA level, the full coding sequences and splice junctions of $p 16^{C D K N 2 A}$ (exons $1 \alpha, 2$, and 3 ) and BRCA2 (exons 1-26) genes were screened for mutations using denaturing highperformance liquid chromatography (DHPLC) on a Wave $^{\circledast}$ nucleic acid fragment analysis system (Transgenomic, Santa Clara, CA). As previously reported by our group[28], abnormal PCR products identified by DHPLC analysis were directly sequenced using an automated fluorescence- cycle sequencer (ABIPRISM 3130, Applied Biosystems, Foster City, CA). About half of the present cohort (437 patients) has been already tested for $p 16^{\mathrm{CDKN2A}}$ germline mutations in our previous study [11]. Subsets of Sardinian patients originating from all geographical areas within the island were screened for mutations in the $M C 1 R$ gene as above. At somatic DNA level, the full coding sequences and splice junctions of p16CDKN2A, NRAS (exons 2-3), and BRAF (exons 2-17) genes were screened for mutations as above. Primer sets and protocols for polymerase chain reaction (PCR) assays were as previously described $[11,20,28,29]$. For melanoma cell lines, we also performed mutation analysis of the PTEN gene (exons 1-9); primer sequences were as reported in Genome DataBase (GDB at http://www.gdb.org).

To evaluate the prevalence of each gene variant in a control population, unrelated healthy individuals, originating from the same geographical areas and with no recurrence of cancer in family, were used as controls and screened for sequence variations.

\section{Immunochemical analysis}

Immunocytochemistry was performed on cultured melanoma cells, using standard procedures. Melanoma cell lines were kindly provided by Dr. Stefania D'Atri at the Institute Dermopatico dell'Iacolata in Rome. They were established as primary short term cell cultures starting from tumour samples of donors patients with documented diagnosis of melanoma, after obtaining their informed consent Immunocytochemical analysis was performed using primary monoclonal antibodies against p16CDKN2A (JC-2 Lab Vision-Neo-Markers, Fremont, CA) and pERK $_{1-2}$ (Santa Cruz Biotechnology, Santa Cruz, CA) proteins.
Immunocytochemical staining was evaluated semi-quantitatively, using antibody negative and positive controls. Intensity and distribution of immunostaining was used to classify cells as positive (strong $[+++]$ to moderate $[++]$ staining, homogeneously distributed or presented by large majority of tumour cells) or negative (absent [-] or weak staining $[+]$ ) for gene expression. Scoring was performed by at least two investigators (in very few borderline cases, classification of immunostaining required additional investigators and was based on the consistency of the majority of them).

\section{Statistical analysis}

Statistical correlation between $M C 1 R$ germline mutations and disease was performed by chi-square test. Odds ratios of carrying gene mutations were estimated by the logistic regression model and are reported with $95 \%$ confidence interval $(95 \% \mathrm{CI})$. Features for the relative risk calculation were analyzed as dichotomous variables (presence versus absence). The exact coefficient for sample proportion analysis was performed to determine all significant parameters (below 0.05 level). All analyses were performed using the statistical package SPSS/7.5 per Windows.

\section{Results \\ Predisposing mutations in melanoma}

Genomic DNA from 301 melanoma patients with ascertained Sardinian origin and 545 melanoma cases originating from non-Sardinian southern Italian regions was screened for germline mutations of $p 16^{C D K N 2 A}$, the main melanoma susceptibility gene. PCR products corresponding to the coding exons and intron-exon junctions were analyzed for mutations as described in Methods. For p16CDKN2A gene, 7 germline mutations were detected in 16/545 (2.9\%) non-Sardinian patients (Table 1). All mutations have been reported as disease-related variants in the Human Gene Mutation Database at http:// archive.uwcm.ac.uk; the S12X and E26X mutations were classified as disease-causing variants due to their truncation effect on proteins. In particular, six (17.1\%) p16 CDKN2A mutation carriers were among 35 melanoma patients who had at least one additional affected members in the family; the remaining ten $(2.0 \%)$ p $16^{C D K N 2 A}$ mutation carriers were among 510 melanoma patients with sporadic disease (Table 2). None of 301 Sardinian patients was found positive for germline mutations in such a gene (Table 2). All p16 $6^{C D K N 2 A}$ mutations were absent in normal genomic DNA from 103 unrelated healthy individuals (corresponding to 206 control chromosomes), originating from the same geographical areas.

The $p 16^{C D K N 2 A}$ remained a melanoma susceptibility gene for non-Sardinian patients only; its involvement into the disease was absent among Sardinian patients. Therefore, 
Table I: Germline mutations in p 16 ${ }^{C D K N 2 A}$ and BRCA2 genes.

\begin{tabular}{|c|c|c|c|c|c|}
\hline Gene & Nucleotide & Codon & Base Change & Amino Acid Change & Designation \\
\hline PI 6CDKN2A & 35 & 12 & $C$ to $A$ & Ser to Stop & $S I 2 X$ \\
\hline PI 6CDKN2A & 71 & 24 & $G$ to $C$ & Arg to Pro & $\mathrm{A} 24 \mathrm{P}$ \\
\hline$P / 6 C D K N 2 A$ & 76 & 26 & $\mathrm{G}$ to $\mathrm{T}$ & Glu to Stop & $E 26 X$ \\
\hline PI6CDKN2A & 106 & 36 & $\mathrm{G}$ to $\mathrm{A}$ & Ala to Thr & $\mathrm{A} 36 \mathrm{~T}$ \\
\hline PI 6CDKN2A & 176 & 59 & $\mathrm{~T}$ to $\mathrm{G}$ & Val to Gly & V59G \\
\hline PI 6CDKN2A & 301 & 101 & $\mathrm{G}$ to $\mathrm{T}$ & Gly to Trp & GIOIW \\
\hline$P / 6 C D K N 2 A$ & 326 & 109 & $\mathrm{C}$ to $\mathrm{T}$ & Ala to $\mathrm{Val}$ & Al09V \\
\hline$B R C A 2$ & 8503 & 2835 & $\mathrm{~T}$ to $\mathrm{C}$ & Ser to Pro & Ser2835Pro \\
\hline$B R C A 2$ & 8765 & 2845 & $\operatorname{del} A G$ & Stop 2867 & 8765delAG \\
\hline
\end{tabular}

we investigated whether additional candidate genes, such as BRCA2 and MC1R, might play a role in melanoma susceptibility within such an isolated population. Again, mutation screening for all coding regions and splice boundaries of BRCA2 and MC1R genes was performed as above.

Four (1.3\%) out of 301 Sardinian patients were found to carry germline mutations in coding regions of the BRCA2 gene (three cases with BRCA2-8765delAG and the remaining one with BRCA2-Ser2835Pro); conversely, no BRCA2 mutation was observed in a subset of 154 non-Sardinian patients (to avoid any bias, mutation analysis for BRCA2 gene was performed on first 154 consecutivelycollected cases from South Italy) (Table 2). Interestingly, all BRCA2 mutations of our series were detected in the subset of patients originating from North Sardinia (4/91; $4.4 \%$ ); one BRCA2-positive case was among 4 patients with familial recurrence of melanoma, whereas the remaining three $(3.4 \%)$ BRCA2-positive cases were among 87 patients with sporadic melanoma (Table 2).
Both BRCA2 mutations were classified as disease-causing variants due to their predicted effect on proteins; they have been previously reported into the Breast Cancer Information Core (BIC) database at http:// research.nhgri.nih.gov/bic/. Again, all BRCA2 mutations were not detected in normal genomic DNA from 103 unrelated Sardinian healthy individuals (corresponding to 206 control chromosomes). Cases with either familial or sporadic melanoma originating from other areas of the Sardinia island presented no germline mutation in BRCA2 gene (Table 2).

The entire coding region of the MC1R gene was then screened for germline sequence variations in 269 Sardinian melanoma patients (32 cases of our series were excluded because of DNA degradation or low amount of available genomic DNA) and 102 control subjects who were chosen as representative of the individuals living in the same geographical area and comparable for sex, age, general phenotype, and phototype to melanoma patients. Overall, 20 different $M C 1 R$ variants were found; they were

Table 2: Distribution of germline mutations in p $16^{C D K N 2 A}$ and BRCA2 genes according to patients' origin

\begin{tabular}{|c|c|c|c|c|}
\hline \multirow{2}{*}{$\begin{array}{l}\text { Analyzed gene } \\
\text { Patients' origin }\end{array}$} & & \multirow[t]{2}{*}{ No. of analyzed patients } & \multicolumn{2}{|c|}{ Positive cases } \\
\hline & & & No. & $\%$ \\
\hline CDKN2A & & 846 & 16 & 1.9 \\
\hline \multirow[t]{3}{*}{ non-Sardinian } & & 545 & 16 & 2.9 \\
\hline & Familial & 35 & 6 & I7.1 \\
\hline & Sporadic & 510 & 10 & 2.0 \\
\hline \multirow[t]{3}{*}{ Sardinian } & & 301 & \multicolumn{2}{|c|}{0} \\
\hline & Familial & 10 & \multicolumn{2}{|c|}{0} \\
\hline & Sporadic & 291 & \multicolumn{2}{|c|}{0} \\
\hline BRCA2 & & 455 & 4 & 0.9 \\
\hline non-Sardinian & & 154 & \multicolumn{2}{|c|}{0} \\
\hline Sardinian & & 301 & 4 & 1.3 \\
\hline \multirow[t]{3}{*}{ North Sardinia } & & 91 & 4 & 4.4 \\
\hline & Familial & 4 & 1 & 25.0 \\
\hline & Sporadic & 87 & 3 & 3.4 \\
\hline \multirow[t]{3}{*}{ Middle-South Sardinia } & & 210 & \multicolumn{2}{|c|}{0} \\
\hline & Familial & 6 & \multicolumn{2}{|c|}{0} \\
\hline & Sporadic & 204 & \multicolumn{2}{|c|}{0} \\
\hline
\end{tabular}


classified according to the effect of the gene sequence variations on the protein function [partial (r) or complete (R) loss of the receptor's signalling ability, as previously reported [20] (Table 3). Two MC1R germline variants classified as "R", Arg151Cys [odds ratio (OR), 6.4; 95\% confidence interval (95\% CI), 2.1-15.9] and Asp294 His (OR, $1.8 ; 95 \% \mathrm{CI}, 1.1-5.3$ ), were significantly associated with melanoma in our series (Table 3 ). Considering the individuals who were either homozygous or heterozygous for the " $R$ " variant of the MC1R gene, the occurrence of such $a$ " $R$ " allele into the genotype was significantly associated with melanoma ( $\mathrm{p}=0.043 ; \mathrm{OR}, 2.3 ; 95 \% \mathrm{CI}, 1.2-7.8)$ (Table 4). No phenotypic parameter in our series of melanoma patients [sex, age of onset, primary tumour location, stage of disease, family history of melanoma, or geographical origin (North vs. Middle-South Sardinia)] was statistically correlated with the presence of the "R" genotype in $M C 1 R$ gene (data not shown).

\section{Pathogenetic alterations in melanoma}

A high prevalence of somatic mutations was detected in a subset of paired primary and secondary (lymph node metastasis) melanomas from 35 patients of the series (Table 5). Confirming previously reported data, BRAF and NRAS mutations were mutually exclusive in our patients' collection; overall, BRAF or NRAS mutations were detected in 23/34 (68\%) primary tumours and 24/35 (69\%) lymph node metastases from the same melanoma patients (Table 5). With the exception of one BRAF mutation (L597R) occurred in metastatic sample only, no difference in rates and types of mutations in BRAF and NRAS genes was observed between primary and secondary tumour tissues from same patients (Table 5). The rate of mutations in $p 16^{C D K N 2 A}$ gene was found to instead increase from primary to metastatic melanomas of the same patients [5/33 (15\%) to $8 / 35(23 \%)$, respectively] (Table 5); in this sense, an even higher prevalence of p16CDKN2A alterations [8 (44\%) gene mutations or hemihomozygous exon deletions; 11 (61\%) gene down-regulations] was observed in our series of 18 melanoma cell lines (Table 6). Conversely, a quite similar rate of BRAFNRAS mutations $(11 / 18 ; 61 \%)$ was detected in melanoma cell lines when compared to the uncultured melanomas (Table 6). Again, all detected mutations have been previously reported in the Human Gene Mutation Database at http://archive.uwcm.ac.uk.

\section{No PTEN mutation was found in melanoma cell lines}

Considering the immunocytochemical results, all melanoma cell lines $(7 / 7 ; 100 \%)$ with concurrent mutation of BRAF-NRAS and down-regulation of $p 16^{C D K N 2 A}$ presented high expression levels of the activated pERK $_{1-2}$ protein (Figure 1). The remaining subsets of melanoma cell lines with alterations of one or none of such genes presented lower rates of ERK1-2 phosphorilation [5/8 $(62 \%)$ and $1 / 3(33 \%)$, respectively] (Figure 1), suggesting that coexistence of multiple molecular events may be required for activating ERK in melanoma. In Figure 2, the expression of ERK1, ERK2, and pERK $_{1-2}$ proteins was validated by Western blot hybridization in M14 and PR-Mel melanoma cell lines.

Table 3: Distribution of MCIR variants among Sardinian melanomas and controls

\begin{tabular}{|c|c|c|c|c|c|c|}
\hline MCIR variants & Landi's classification & Positive cases $(\mathrm{N}=\mathbf{2 6 9})$ & $\%$ & Positive controls $(\mathrm{N}=102)$ & $\%$ & $\mathbf{P}$ \\
\hline Val60leu (V60L) & $\mathrm{R}$ & 88 & 32.7 & 32 & 31.4 & n.s. \\
\hline Ser83Pro (S83P) & $\mathrm{R}$ & 3 & 1.1 & I & 1.0 & n.s. \\
\hline Asp84Glu (D84E) & $\mathrm{R}$ & 1 & 0.4 & 0 & 0 & n.s. \\
\hline Val92Met (V92M) & $\mathrm{R}$ & 16 & 5.9 & 5 & 4.9 & n.s. \\
\hline Thr95Met (T95M) & $\mathrm{R}$ & 3 & 1.1 & I & 1.0 & n.s. \\
\hline Gly 104Ser (GI04S) & $\mathrm{R}$ & 2 & 0.7 & I & 1.0 & n.s. \\
\hline Arg|42Cys (RI42C) & $\mathrm{R}$ & I & 0.4 & 0 & 0 & n.s. \\
\hline $\mathrm{Arg} \mid 42 \mathrm{His}(\mathrm{R} \mid 42 \mathrm{H})$ & $\mathrm{R}$ & 9 & 3.3 & 3 & 2.9 & n.s. \\
\hline Arg I5 ICys (RI5IC) & $\mathbf{R}$ & 19 & 7.1 & $\mathbf{I}$ & 1.0 & $>0.01$ \\
\hline Tyr I52Term (YI52Term) & $\mathrm{R}$ & I & 0.4 & 0 & 0 & n.s. \\
\hline Ilel55Thr (II55T) & $\mathrm{R}$ & 4 & 1.5 & 2 & 2.0 & n.s. \\
\hline $\operatorname{Arg} 160 \operatorname{Trp}(\mathrm{R} \mid 60 \mathrm{~W})$ & $\mathbf{R}$ & 13 & 4.8 & 3 & 2.9 & 0.136 \\
\hline Argl63Gln (RI63Q) & $\mathrm{R}$ & 7 & 2.6 & 2 & 2.0 & n.s. \\
\hline Ser I72Ile (SI72I) & $\mathrm{R}$ & I & 0.4 & 0 & 0 & n.s. \\
\hline $\operatorname{Arg} 213 \operatorname{Trp}(\mathrm{R} 213 \mathrm{~W})$ & $\mathrm{R}$ & 5 & 1.9 & I & 1.0 & n.s. \\
\hline Ile22IThr (I 22I T) & $\mathrm{R}$ & I & 0.4 & 0 & 0 & n.s. \\
\hline Pro256Ser (P256S) & $\mathrm{R}$ & 2 & 0.7 & 0 & 0 & n.s. \\
\hline Asp294His (D294H) & $\mathbf{R}$ & 31 & 11.5 & 5 & 4.9 & 0.048 \\
\hline Thr308Met (T308M) & $\mathrm{R}$ & 2 & 0.7 & 0 & 0 & n.s. \\
\hline InsA724 & $\mathrm{R}$ & 2 & 0.7 & 0 & 0 & n.s. \\
\hline
\end{tabular}

$M C I R$ variants with complete loss of function are defined as "R" (in bold), whereas variants with partial loss of function are defined as " $r$ ". $P$ values (chi-squared test; two tailed; 95\% confidence interval) were given for MCIR-"R" variants only. n.s., not significant 
Table 4: Frequency of R-containing genotypes in MCIR gene among Sardinian melanomas and controls

\begin{tabular}{llcc}
\hline & \multicolumn{3}{l}{ Positive cases } \\
Subgroups (No. of subjects) & No. & $\%$ & $P$ \\
\hline $\begin{array}{l}\text { Patients }(269) \\
\quad R / R \text { or } R / r \text { or } R / \text { wt genotypes }\end{array}$ & 63 & 23.4 & $0.04 I$ \\
$\begin{array}{c}\text { Controls }(102) \\
\text { R/R or } R / r \text { or } R / \text { wt genotypes }\end{array}$ & 9 & 8.8 & \\
\hline
\end{tabular}

\section{Discussion}

Melanocytic transformation is thought to occur by sequential accumulation of alterations in several genes and metabolic pathways $[8,30,31]$. In our study, we tried to better define the role of the genes mainly involved in melanoma susceptibility (through the assessment of the prevalence of predisposing germline mutations) and pathogenesis (by investigating somatic gene down- or upregulations in tumour tissues and cancer cell lines).

\section{Melanoma susceptibility}

Assessment of the prevalence of predisposing germline mutations in candidate genes represents an important step toward prevention and early detection of cancers. In this sense, the mutation analysis of $p 16^{C D K N 2 A}$, which is the main gene associated with melanoma susceptibility $[8,30]$, should be considered as a crucial step. Due to environmental and genetic factors, prevalence of $p 16^{C D K N} 2 \mathrm{~A}$ mutations has been demonstrated to deeply vary among different populations [10]. A real estimation of the proportion of positive and negative tests that might be expected in a referral risk evaluation clinic is therefore fundamental to provide clinical recommendations for p16 ${ }^{\mathrm{CDKN} 2 A}$ genetic testing.

Table 5: Somatic mutations in BRAF, NRAS, and p $16^{C D K N 2 A}$ genes among in vivo melanoma tissues

\begin{tabular}{|c|c|c|c|c|c|c|c|c|}
\hline \multirow[t]{2}{*}{ Case } & \multirow[t]{2}{*}{ Sex } & \multirow[t]{2}{*}{ Age at diagnosis } & \multicolumn{3}{|c|}{ Primary tumour } & \multicolumn{3}{|c|}{ Lymph node metastasis } \\
\hline & & & $B R A F$ & NRAS & $p / 6 C D K N 2 A$ & BRAF & NRAS & p/6CDKN2A \\
\hline MNOI & M & 43 & & & & L597R & & \\
\hline MN02 & $\mathrm{F}$ & 63 & & Q6IR & & & Q6IR & \\
\hline MN03 & $M$ & 51 & V600E & & & V600E & & \\
\hline MN04 & $M$ & 40 & V600E & & & V600E & & \\
\hline MN06 & $M$ & 49 & V600E & & & V600E & & \\
\hline MN07 & $M$ & 39 & V600E & & & V600E & & \\
\hline MN08 & $\mathrm{F}$ & 65 & & Q6IR & & & Q6IR & \\
\hline MN09 & $M$ & 34 & & Q6IR & & & Q6IR & \\
\hline MNIO & $M$ & 67 & V600E & & Arg24Pro & V600E & & Arg24Pro \\
\hline MNII & $M$ & 84 & V600K & & & V600K & & \\
\hline MNI2 & $M$ & 74 & & & & & & \\
\hline $\mathrm{MNI4}$ & $M$ & 41 & & & n.t. & & & \\
\hline MNI5 & $M$ & 63 & & & & & & Arg80ter \\
\hline MNI 8 & $M$ & 75 & & & & & & \\
\hline MNI9 & $M$ & 30 & V600E & & & V600E & & \\
\hline MN20 & $\mathrm{F}$ & 45 & V600E & & & V600E & & \\
\hline MN2I & $M$ & 35 & & & Ala36Thr & & & Ala36Th \\
\hline MN22 & $M$ & 71 & & Q6IR & & & Q6IR & \\
\hline MN25 & $\mathrm{F}$ & 35 & V600E & & & V600E & & \\
\hline MN26 & $M$ & 50 & & Q6IR & & & Q6IR & \\
\hline MN27 & $\mathrm{F}$ & 48 & & & & & & \\
\hline MN28 & $\mathrm{F}$ & 58 & & Q6IK & & & Q6IK & \\
\hline MN29 & $M$ & 51 & V600E & & & V600E & & \\
\hline MN3I & $M$ & 40 & & Q6IR & & & Q6IR & \\
\hline MN34 & $\mathrm{F}$ & 65 & & Q6IR & Alal09Val & & Q6IR & Ala I09Val \\
\hline MN35 & $M$ & 61 & & & & & & \\
\hline MN36 & $M$ & 64 & & & TrpII0ter & & & Trpl I0ter \\
\hline MN4I & $\mathrm{F}$ & 69 & & & & & & \\
\hline MN45 & $\mathrm{F}$ & 56 & n.t. & n.t. & n.t. & & & Arg80ter \\
\hline MN05 & $M$ & 51 & V600E & & & V600E & & $|V S|+\mid G>A$ \\
\hline MN55 & $\mathrm{F}$ & 34 & & & & & & \\
\hline MN56 & $\mathrm{F}$ & 36 & V600E & & & V600E & & \\
\hline MN59 & $\mathrm{F}$ & 53 & & Q6IK & & & Q6IK & \\
\hline MN68 & $M$ & 45 & & Q6IR & & & Q6IR & \\
\hline MN75 & $\mathrm{F}$ & 56 & & Q6IR & Arg24Pro & & Q6IR & Arg24Pro \\
\hline
\end{tabular}

Primary melanomas are in bold. n.t., not tested 
Table 6: Genetic and functional alterations in candidate genes among in vitro melanoma cell lines

\begin{tabular}{|c|c|c|c|c|c|c|c|}
\hline $\begin{array}{l}\text { Cell line } \\
\text { derived from }\end{array}$ & ERKI & ERK2 & PERK & pl6 & BRAF & NRAS & pl6CDKN2A \\
\hline \multicolumn{8}{|c|}{ Primary melanoma } \\
\hline GR-Mel & +++ & ++ & + & ++ & & & \\
\hline LCP-Mel & +++ & +++ & ++ & + & V600R & & Del exon 2 \\
\hline MNG & +++ & +++ & $++/+++$ & + & & & \\
\hline PNP-Mel & +++ & +++ & ++ & + & V600E & & GIOIW \\
\hline ST-Mel & $++/+++$ & +++ & +++ & ++ & G466E & & \\
\hline \multicolumn{8}{|c|}{ Metastatic lymph node } \\
\hline CN-Mel & +++ & +++ & ++ & + & & Q6IR & \\
\hline CR-Mel & +++ & +++ & ++ & + & & Q6IK & Del exon 2 \\
\hline GL-Mel & +++ & +++ & ++ & + & & & Del exon 2 \\
\hline LCM-Mel & +++ & ++ & ++ & - & V600R & & Del exons I-2 \\
\hline MAR & +++ & $+/++$ & + & + & & & \\
\hline SK-Mel-28 & +++ & ++ & ++ & +++ & V600E & & \\
\hline I 3443-Mel & +++ & ++ & + & +++ & & & \\
\hline \multicolumn{8}{|c|}{ Cutaneous metastasis } \\
\hline LB-24-Mel & +++ & +++ & +++ & ++ & & & \\
\hline MI4 & +++ & +++ & ++ & + & V600E & & 455insCdel26 IVS I+2T>C \\
\hline PR-Mel & +++ & +++ & + & ++ & V600R & & \\
\hline SN-Mel & ++ & $++/+++$ & + & ++ & V600E & & \\
\hline WM-266-4 & +++ & ++ & $++/+++$ & - & V600D & & Del exon I \\
\hline 397-Mel & ++ & ++ & ++ & + & & & Del exon 2 \\
\hline
\end{tabular}

In our analysis, $p 16^{C D K N 2 A}$ germline mutations were detected in about $3 \%(16 ; 2.9 \%)$ out of 545 melanoma patients from southern Italian regions not including Sardinia; in this island, none of the 301 analyzed patient was found to carry a $p 16^{C D K N 2 A}$ mutation. When Sardinian patients were screened for germline mutations in BRCA2 gene, which seems to play a major role in predisposition to different types of cancer including melanoma (although data are still insufficient, annual skin and eye examinations for early diagnosis of melanoma have been proposed for genetic counselling of BRCA2 carriers) [11$14]$, we exclusively observed a mutated BRCA2 gene in patients originating from North Sardinia (4/91;4.4\%); no BRCA2 germline mutation was observed in 210 patients originating from the remaining areas of the island or in a subset of 154 non-Sardinian melanoma cases (see Table 2 ). Moreover, we obtained evidence that no sequence variation was present in $p 15^{C D K N 2 B}$ and $C D K 4$, the remaining two high penetrance melanoma susceptibility genes, among familial melanoma cases from our southern Italian population ([32] and unpublished data). Therefore, the central-southern part of the Sardinia island should be considered as a geographical area in which melanoma patients do not carry mutations in any known major susceptibility gene. Since the incidence rates of melanoma are quite similar in both Sardinian, genetically homogeneous, and non-Sardinian, genetically heterogeneous, populations from South Italy (roughly, 4 new cases per 100.000 inhabitants per year [5]), our findings seem to further confirm that genetic factors predisposing to melanoma are geographically heterogeneous and strictly depending on patients' origin. On this regard, it is worth to underline that Sardinia island has a relatively small and isolated population with a high rate of inbreeding; in comparison to the genetically-heterogeneous Italian population, a higher prevalence of mutations with founder effect has been reported (even for cancer diseases) $[33,34]$. Nevertheless, one could speculate that prevalence of mutations in melanoma susceptibility genes needs to be investigated in every different geographical area.

Considering the familial recurrence of melanoma, 48/846 (5.7\%) patients from our series presented at least one additional affected member in the family. Overall, seven (14.6\%) melanoma families had a detectable mutation in p16CDKN2A or BRCA2 gene. Also considering some lack of sensitivity of the mutation analysis approach, the prevalence of such germline mutations among patients with familial melanoma from South Italy remains low. However, vast majority of the families included into the present study contains two melanoma patients only; therefore, more stringent selection criteria or subcriteria should be used in order to reduce chances that the identified melanoma families may simply represent a cluster of sporadic cases. As a confirmation of this hypothesis, a consistent increase in prevalence rate of $p 16^{C D K N 2 A}$ mutations was observed among families with three affected members $(3 / 7 ; 42.9 \%)$. Although large genomic deletions may escape detection by direct sequencing, undetected mutations are unlikely to explain the high number of fam- 

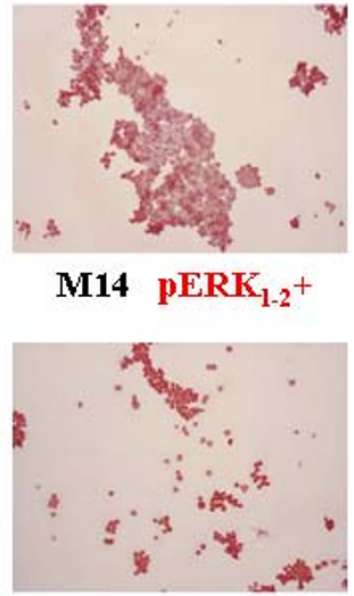

M14 ERK2

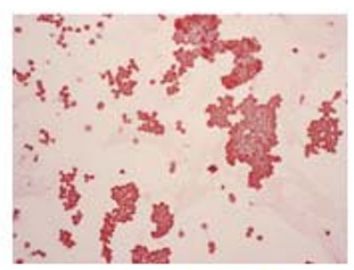

M14 ERK1

\begin{tabular}{|c|c|c|}
\cline { 2 - 3 } \multicolumn{1}{c|}{} & pERK $_{1-2^{+}}$ & pERK $_{1-2^{-}}$ \\
\hline $\begin{array}{c}\text { BRAF/NRAS mut } \\
\text { p16- }\end{array}$ & $\begin{array}{c}7 \\
(100 \%)\end{array}$ & 0 \\
\hline $\begin{array}{c}\text { BRAF/NRAS wt } \\
\text { p16- }\end{array}$ & $\begin{array}{c}3 \\
(75 \%)\end{array}$ & $\begin{array}{c}1 \\
(25 \%)\end{array}$ \\
\hline $\begin{array}{c}\text { BRAF/NRAS mut } \\
\text { p16+ }\end{array}$ & $\begin{array}{c}2 \\
(50 \%)\end{array}$ & $\begin{array}{c}2 \\
(50 \%)\end{array}$ \\
\hline $\begin{array}{c}\text { BRAF/NRAS wt } \\
\text { p16+ }\end{array}$ & $\begin{array}{c}1 \\
(33 \%)\end{array}$ & $\begin{array}{c}2 \\
(67 \%)\end{array}$ \\
\hline
\end{tabular}

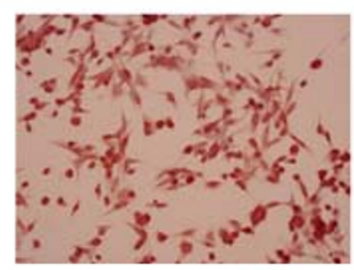

13443-Mel p16+

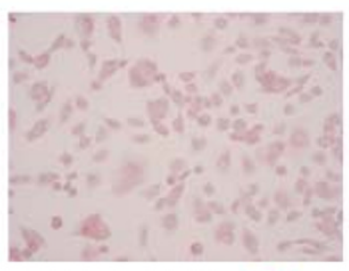

WM-266-4 p16-

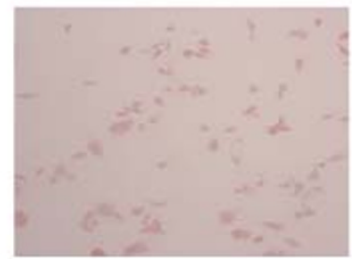

PR-Mel pERK 1-2- $^{-}$
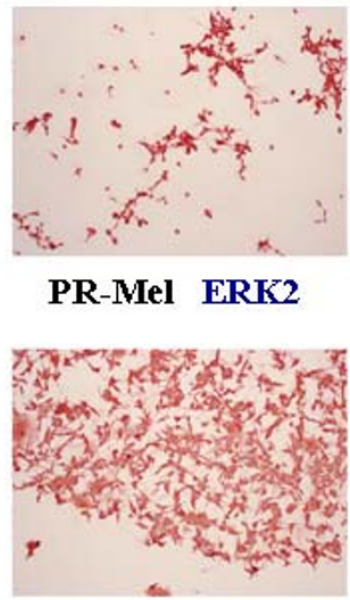

PR-Mel ERK1

\section{Figure I}

Classification of melanoma cell lines according to alterations in NRAS/BRAF genes and $\mathrm{p} \mathrm{I} \mathrm{6CDKN2A/pERK}_{\mathrm{I}-2} \mathrm{Pro}$ tein expression. Data regarding occurrence of mutations in BRAF/NRAS genes (mut), down-regulation of $\mathrm{p} / 6 \mathrm{CDKN2A}$ protein (p I6-), and over-expression of phosphorilated $E R K_{I-2}$ protein $\left(p E R K_{I-2}+\right)$ are indicated. Exemplificative immunochemical results are shown.

ilies without mutations. Therefore, these data further support the hypothesis that additional low-penetrance melanoma susceptibility genes remain to be identified.

Finally, our study confirmed the association of some $M C 1 R$ gene variants with the occurrence of cutaneous melanoma as previously reported $[15,35,36]$. Despite the $M C 1 R$ sequence screening was carried out among Sardinian patients only (due to the availability of control subjects representative of the individuals living in the island and comparable for phenotypic features to melanoma patients), the variants classified as " $R$ " and, particularly, the Arg151Cys and Asp294His alleles appeared to be associated with melanoma. Considering the functional outcome, both Arg151Cys and Asp294His variants have been demonstrated to affect the normal signalling of the melanocortin-1 receptor by reducing the ability to elevate the intracellular levels of cAMP [16]. Further and more specific studies (based on better classification of the different skin phototypes and/or a more detailed evaluation of the general phenotypic characteristics) are required in order to define the role of such MC1R gene variants into the susceptibility to melanoma.

\section{Melanoma pathogenesis}

We here examined the relationship between alterations in NRAS, BRAF, and p16CDKN2A genes in both in vivo melanoma tissues $(\mathrm{N}=35)$ from southern Italian patients and in vitro melanoma cell lines $(\mathrm{N}=18)$. We found that mutually exclusive mutations of NRAS and BRAF genes occur at quite same rate in cultured and uncultured melanomas (either primary or metastatic lesions), confirming that they represent an early event within the cascade of alterations involved into the melanomagenesis. However, distribution of mutations in each gene (NRAS or $B R A F$ ) deeply varied into the analyzed somatic samples from our series (see Tables 5 and 6), suggesting that pathogenetic alterations may indifferently affect kinases acting either up- or downstream within such a signalling cascade. Moreover, no concurrent mutation of the PTEN gene was observed in melanoma cell lines; this is clearly in contrast with previous data from other series, which reported that such a gene is mutated at a rate of about $30 \%$ among in vitro melanomas [37]. Conversely, p16CDKN2A gene mutations and/or rearrangements (mostly, represented by exon deletions) were observed at increased rates moving from primary to metastatic 


\section{PR-Mel M14}

\section{ERK1}

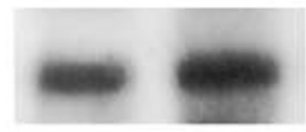

ERK2

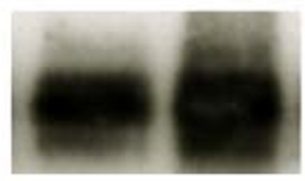

pERK $_{1-2}$

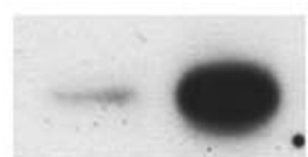

\section{Figure 2}

Western blot analysis of MI4 and PR-Mel melanoma cell lines. Protein lysates from MI4 and PR-Mel cells were resolved by SDS-PAGE gel electrophoresis and transferred to a nylon membrane; the proteins on the membrane were then subjected to immunoblot analysis with antibodies against ERK I-2/PERK ${ }_{I-2}$ proteins.

melanomas and melanoma cell lines (see Tables 5 and 6). Down-regulation or inactivation of the $p 16^{C D K N 2 A}$ gene (in our series, about two thirds of melanoma cell lines presented a reduced or absent expression of the $p 16$ CDKN $2 A$ protein) has been demonstrated to affect the control of cell growth, which may induce cell proliferation and increase aggressiveness of transformed melanocytic cells (melanoma cells tend to inactivate both alleles of such a tumour suppressor gene) [38].

Presence of $B R A F$ mutations in benign and dysplastic nevi [39] supports the hypothesis that activation of the NRAS$B R A F-E R K$ pathway is not sufficient to induce the malignant process and fully transform proliferating melanocytes, but requires additional, cooperating de-regulative events. In our series, the increased activity of ERK1/2 proteins was mainly a consequence of a combination of mutations in upstream NRAS/BRAF components of the pathway and silencing of the $p 16^{C D K N 2 A}$ gene (although additional - and yet unidentified - functional alterations may participate in inducing such a ERK activation) (see Figure 1). Therefore, our data provide an additional confirmation that multiple molecular events are being accumulated during melanomagenesis.

Identification of the predominant germline mutations in candidate susceptibility genes within a particular geographical area has particular relevance to achieve a prediction of the melanoma risk as well as to address patients and their families to clinical screening. On this regard, a dramatic improvement toward an earlier diagnosis of melanoma could be represented by the selection of specific high-risk groups to be appropriately targeted (since routine screening for detection of thinner melanoma can not be indiscriminately proposed). Familial melanoma patients are reported to present with thinner melanomas [8]. As also indicated above, different classifications of familial melanoma have been used by several authors, based on number (two cases with additional and various subcriteria or at least three cases) and type (involvement of first- and/or second-degree relatives) of affected family members. Regardless the occurrence of a weak or strong family history, relatives of melanoma patients carrying germline mutations in susceptibility genes could represent a high risk group which might undergo a surveillance program for identification of thinner melanoma. Our experience seems to support this hypothesis. Considering the non-Sardinian melanoma patients (whose series was the only one in which we detected $p 16^{C D K N 2 A}$ germline mutations), first- and second-degree relatives of p16 ${ }^{C D K N 2 A}$ mutation carriers were informed to belong to a putative high risk group (through specific educational sessions, after obtaining an informed consent) and addressed to a short-term ( 6 months) surveillance program using epiluminescence microscopy. After a median follow-up of 78 months (range, 37-109), six new melanomas with median Breslow thickness of $0.35 \mathrm{~mm}$ (range, 0.25-0.68) were observed among such relatives of p16 ${ }^{C D K N 2 A}$ mutation-positive patients (it is important to underline that patients with very thin melanomas - Breslow thickness $\leq 0.40 \mathrm{~mm}$ - present a 10-year survival rate which is estimated to be more than 98\% [40,41]). Although the number of events for more mature and definitive results is really low, we could speculate that the identification of a melanoma patient carrying a $p 16^{C D K N} 2 \mathrm{~A}$ germline mutation should induce clinicians to educate his family members to have a great care of all skin lesions and pay high attention to noticing any nevi' modification as well as to address them to a routine screening for detection of thinner melanoma.

\section{Conclusion}

Although most genetic and molecular alterations have been identified, characterization of all interactions between key effectors in MAPK, CDKN2A, and additional (i.e. PTEN-AKT) pathways will represent the aims of future research efforts, in order to further clarify the sequence of events inducing transformation of melanocytes and progression of melanoma.

\section{Competing interests}

The authors declare that they have no competing interests.

\section{Authors' contributions}

MC performed all mutation analyses. AM participated to patients' collection. AC participated to the collection of 
somatic samples. $\mathrm{MB}$ participated to analysis and interpretation of data. CC participated to patients' collection. PAA participated to patients' collection. EP participated to characterization of melanoma cell lines. IS participated to patients' collection. SC participated to patients' collection. MS performed immunochemical analyses. GrP participated to mutation analysis and cell biology. GiP conceived of the study and drafted the manuscript.

\section{All authors read and approved the final manuscript.}

\section{Acknowledgements}

Other investigators involved in this study and considered as co-authors: Carlo Mulas, Daniela Capra (Ospedale Oncologico Businco, Cagliari, Italy); Maria P. Satta (Istituto Chimica Biomolecolare-CNR, Sassari, Italy); Antonio Vozza (Seconda Università, Napoli, Italy). Members of the Italian Melanoma Intergroup (IMI): Vanna Chiaron Sileni, Franco Di Filippo, Michele Maio, Giorgio Parmiani, Paola Queirolo, Ruggero Ridolfi, CarloRiccardo Rossi, Alessandro Testori. We thank Assunta Criscuolo, for data management. Authors are grateful to patients for their important contribution to this study. Work was supported by Italian Ministry of Health "Progetto Ricerca Finalizzata", Schering-Plough Inc., and Sardinia Regional Government (Regione Autonoma della Sardegna).

\section{References}

I. de Vries E, Coebergh JW: Melanoma incidence has risen in Europe. BM] 2005, 331:698.

2. Lipsker D, Engel F, Cribier B, Velten M, Hedelin G: Trends in melanoma epidemiology suggest three different types of melanoma. Br J Dermatol 2007, 157:338-343.

3. Welch HG, Woloshin S, Schwartz LM: Skin biopsy rates and incidence of melanoma: population based ecological study. $B M$ J 2005, 33I:48I.

4. de Vries E, Bray FI, Coebergh JW, Parkin DM: Changing epidemiology of malignant cutaneous melanoma in Europe 19691997 rising trends in incidence and mortality, but recent stabilisations in western Europe and decreases in Scandinavia. Int / Cancer 2003, 107: I 19-126.

5. Curado MP, Edwards B, Shin HR, Storm H, Ferlay J, Heanue M, Boyle $P$, eds: Cancer Incidence in Five Continents. Volume IX. International Agency for Research on Cancer (IARC) Scientific Publications, No. 160 Lyon, IARC; 2007.

6. Bataille V: Genetic epidemiology of melanoma. Eur J Cancer 2003, 39: | 34|- 1347

7. Jhappan C, Noonan FP, Merlino G: Ultraviolet radiation and cutaneous malignant melanoma. Oncogene 2003, 22:3099-3 I I2.

8. Thompson JF, Scolyer RA, Kefford RF: Cutaneous melanoma. The Lancet 2005, 365:687-70I.

9. Cho E, Rosner BA, Feskanich D, Colditz GA: Risk factors and individual probabilities of melanoma for whites. J Clin Oncol 2005, 23:2669-2675.

10. Bishop DT, Demenais F, Goldstein AM, Bergman W, Bishop JN, Bressac-de Paillerets B, Chompret A, Ghiorzo P, Gruis N, Hansson J, Harland M, Hayward N, Holland EA, Mann G], Mantelli M, Nancarrow D, Platz A, Tucker MA, Melanoma Genetics Consortium: Geographical variation in penetrance of CDKN2A mutations for melanoma. J Natl Cancer Inst 2002, 94:894-903.

II. Casula M, Colombino M, Satta MP, Cossu A, Lissia A, Budroni M, Simeone E, Calemma R, Loddo C, Caracò C, Mozzillo N, Daponte A, Comella G, Canzanella S, Guida M, Castello G, Ascierto PA Palmieri $\mathrm{G}$ : Factors predicting the occurrence of germline mutations in candidate genes among patients with cutaneous malignant melanoma from South Italy. Eur J Cancer 2007, 43: I 37- I 43.

12. The Breast Cancer Linkage Consortium: Cancer risks in BRCA2 mutation carriers. J Natl Cancer Inst 1999, 91:1310-1316.

13. Liede A, Karlan BY, Narod SA: Cancer risks for male carriers of germline mutations in BRCAI or BRCA2: a review of the literature. J Clin Oncol 2004, 22:735-742.
14. Sinilnikova OM, Egan KM, Quinn JL, Boutrand L, Lenoir GM, StoppaLyonnet D, Desjardins L, Levy C, Goldgar D, Gragoudas ES: Germline BRCA2 sequence variants in patients with ocular melanoma. Int / Cancer 1999, 82:325-328.

15. Kennedy C, ter Huurne J, Berkhout M, Gruis N, Bastiaens M, Bergman W, Willemze R, Bavinck JN: Melanocortin I receptor (MCIR) gene variants are associated with an increased risk for cutaneous melanoma which is largely independent of skin type and hair color. J Invest Dermatol 200I, I I 7:294-300.

16. Debniak T, Scott RJ, Górski B, Cybulski C, Wetering T van de, Serrano-Fernandez P, Huzarski T, Byrski T, Nagay L, Debniak B, Kowalska E, Jakubowska A, Gronwald J, Wokolorczyk D, Maleszka R, Kładny J, Lubinski J: Common variants of DNA repair genes and malignant melanoma. Eur J Cancer 2008, 44: I |0-1 |4.

17. Beaumont KA, Shekar SN, Newton RA, James MR, Stow JL, Duffy DL, Sturm RA: Receptor function, dominant negative activity and phenotype correlations for MCIR variant alleles. Hum Mol Genet 2007, 16:2249-2260.

18. Raimondi S, Sera F, Gandini S, lodice S, Caini S, Maisonneuve P, Fargnoli MC: MCIR variants, melanoma and red hair color phenotype: a meta-analysis. Int J Cancer 2008, I 22:2753-2760.

19. Kanetsky PA, Rebbeck TR, Hummer AJ, Panossian S, Armstrong BK, Kricker A, Marrett LD, Millikan RC, Gruber SB, Culver HA, Zanetti R, Gallagher RP, Dwyer T, Busam K, From L, Mujumdar U, Wilcox H, Begg CB, Berwick M: Population-based study of natural variation in the melanocortin-I receptor gene and melanoma. Cancer Res 2006, 66:9330-9337.

20. Landi MT, Bauer J, Pfeiffer RM, Elder DE, Hulley B, Minghetti P, Calista $D$, Kanetsky PA, Pinkel D, Bastian BC: MCIR germline variants confer risk for BRAF-mutant melanoma. Science 2006, 313:521-522.

21. Box NF, Duffy DL, Irving RE, Russell A, Chen W, Griffyths LR, Parsons PG, Green AC, Sturm RA: Melanocortin-I receptor genotype is a risk factor for basal and squamous cell carcinoma. J Invest Dermatol 200 I, I 16:224-229.

22. Curtin JA, Fridlyand J, Kageshita T, Patel HN, Busam KJ, Kutzner H, Cho KH, Aiba S, Bröcker EB, LeBoit PE, Pinkel D, Bastian BC: Distinct sets of genetic alterations in melanoma. $N$ Engl J Med 2005, 353:2135-2147.

23. Tsao H, Zhang X, Fowlkes K, Haluska FG: Relative reciprocity of NRAS and PTEN/MMACI alterations in cutaneous melanoma cell lines. Cancer Res 2000, 60:1800-1804.

24. Sensi M, Nicolini G, Petti C, Bersani I, Lozupone F, Molla A, Vegetti C, Nonaka D, Mortarini R, Parmiani G, Fais S, Anichini A: Mutually exclusive NRASQ6 I R and BRAFV600E mutations at the single-cell level in the same human melanoma. Oncogene 2006, 25:3357-3364.

25. Palmieri G, Casula M, Sini MC, Ascierto PA, Cossu A: Issues affecting molecular staging in the management of patients with melanoma. J Cell Mol Med 2007, I I:1052-1068.

26. Davies H, Bignell GR, Cox C, Stephens P, Edkins S, Clegg S, Teague J, Woffendin H, Garnett MJ, Bottomley W, Davis N, Dicks E, Ewing R, Floyd Y, Gray K, Hall S, Hawes R, Hughes J, Kosmidou V, Menzies A, Mould C, Parker A, Stevens C, Watt S, Hooper S, Wilson R, Jayatilake H, Gusterson BA, Cooper C, Shipley J, Hargrave D, Pritchard-Jones K, Maitland N, Chenevix-Trench G, Riggins G], Bigner DD, Palmieri G, Cossu A, Flanagan A, Nicholson A, Ho J, Leung SY, Yuen ST, Weber BL, Seigler HF, Darrow TL, Paterson H, Marais R, Marshall CJ, Wooster R, Stratton MR, Futreal PA: Mutations of the BRAF gene in human cancer. Nature 2002, 417:949-954.

27. Smalley KSM: A pivotal role for ERK in the oncogenic behaviour of malignant melanoma? Int J Cancer 2003, I04:527-532.

28. Palomba G, Pisano M, Cossu A, Budroni M, Dedola MF, Farris A, Contu A, Baldinu P, Tanda F, Palmieri G: Spectrum and prevalence of BRCAI and BRCA2 germline mutations in Sardinian breast cancer patients through a hospital-based screening. Cancer 2005, 104: I 172-1 I79.

29. Budroni M, Cesaraccio R, Coviello V, Sechi O, Pirino D, Cossu A, Tanda F, Pisano M, Palomba G, Palmieri G: Role of BRCA2 mutation status on overall survival among breast cancer patients from Sardinia. BMC Cancer 2009, 9:62.

30. Hayward NK: Genetics of melanoma predisposition. Oncogene 2003, 22:3053-3062.

31. Wolchok JD, Saenger YM: Current topics in melanoma. Curr Opin Oncol 2007, 19: I 16-120. 
32. Casula M, Ascierto PA, Cossu A, Sini MC, Tore S, Colombino M, Satta MP, Manca A, Rozzo C, Satriano SMR, Castello G, Lissia A, Tanda F, Palmieri G: Mutation analysis of candidate genes in melanoma-prone families: evidence of different pathogenetic mechanisms at chromosome 9p21. Melanoma Res 2003, I 3:57|-579.

33. Wright AF, Carothers AD, Pirastu M: Population choice in mapping genes for complex diseases. Nat Genet 1999, 23:397-404.

34. Palomba G, Cossu A, Friedman E, Budroni M, Farris A, Contu A, Pisano $M$, Baldinu $P$, Sini MC, Tanda F, Palmieri G: Origin and distribution of the BRCA2-8765delAG mutation in breast cancer. BMC Cancer 2007, 7:132.

35. Palmer JS, Duffy DL, Box NF, Aitken JF, O'Gorman LE, Green AC, Hayward NK, Martin NG, Sturm RA: Melanocortin-I receptor polymorphisms and risk of melanoma: is the association explained solely by pigmentation phenotype? Am J Hum Genet 2000, 66:176-186.

36. Landi MT, Kanetsky PA, Tsang S, Gold B, Munroe D, Rebbeck T, Swoyer J, Ter-Minassian M, Hedayati M, Grossman L, Goldstein AM, Calista $D$, Pfeiffer RM: MCIR, ASIP, and DNA repair in sporadic and familial melanoma in a Mediterranean population. $J \mathrm{Natl}$ Cancer Inst 2005, 97:998-1007.

37. Goel VK, Lazar AJ, Warneke CL, Redston MS, Haluska FG: Examination of mutations in BRAF, NRAS, and PTEN in primary cutaneous melanoma. J Invest Dermatol 2006, I 26: I 54-160.

38. Haluska FG, Tsao H, Wu H, Haluska FS, Lazar A, Goel V: Genetic alterations in signaling pathways in melanoma. Clin Cancer Res 2006, I 2:230I-2307.

39. Pollock PM, Harper UL, Hansen KS, Yudt LM, Stark M, Robbins CM, Moses TY, Hostetter G, Wagner U, Kakareka J, Salem G, Pohida T, Heenan P, Duray P, Kallioniemi O, Hayward NK, Trent JM, Meltzer PS: High frequency of BRAF mutations in nevi. Nat Genet 2003, 33:19-20.

40. McKinnon JG, Yu XQ, McCarthy WH, Thompson JF: Prognosis for patients with thin cutaneous melanoma: long-term survival data from New South Wales Central Cancer Registry and the Sydney Melanoma Unit. Cancer 2003, 98:I223-I23I.

4I. Gimotty PA, Elder DE, Fraker DL, Botbyl J, Sellers K, Elenitsas R, Ming ME, Schuchter L, Spitz FR, Czerniecki BJ, Guerry D: Identification of high-risk patients among those diagnosed with thin cutaneous melanomas. J Clin Oncol 2007, 25: I I29-I I34.

\section{Pre-publication history}

The pre-publication history for this paper can be accessed here:

http://www.biomedcentral.com/1471-2407/9/352/pre pub
Publish with Bio Med Central and every scientist can read your work free of charge

"BioMed Central will be the most significant development for disseminating the results of biomedical research in our lifetime. "

Sir Paul Nurse, Cancer Research UK

Your research papers will be:

- available free of charge to the entire biomedical community

- peer reviewed and published immediately upon acceptance

- cited in PubMed and archived on PubMed Central

- yours - you keep the copyright
BioMedcentral 